\title{
Constructions of Childhood in Ireland in the Twentieth Century: A View from the Primary School Curriculum 1900- 1999
}

\section{Thomas Walsh}

Our concept of childhood is context-linked and time-specific. This paper traces the evolution of our conceptualisation of childhood in Ireland, focusing particularly on children aged four to six years of age, from 1900 to the present day. In the course of the past century, this perception has altered greatly in light of advancements in society's understanding of children. There has been a gradual transformation in the position of children in society, and the rights and interests of children now receive unprecedented attention in the public domain.

These changes have been influenced, and indeed catalysed, by dramatic social, economic, familial, democratic, religious, cultural and political changes throughout the twentieth century. While there are a number of sources outlining the position of children in society, this paper focuses on documentation from the education system, particularly the content of successive primary school curricula in Ireland. Analysis of documentation provides an insight into society's view and value of children in Ireland in the twentieth century. This is traced in three distinct phases; the curriculum in the period preindependence (1900-1922); the programme adopted upon independence and implemented for close to 50 years (1922-1971); and the revisions that took place and were adopted in the curriculum (1971-1999).

\section{Introduction}

The concept of childhood is context-linked and time-specific (Smyth, 2003, p. 161). Throughout the twentieth century, this concept has been defined and redefined. This construction is facilitated by a number of groups and individuals in society including the State, families, the churches, legal and administrative systems, the media and by

\footnotetext{
Thomas Walsh is a Development Officer with the Centre for Early Childhood Development and Education. Correspondence to: Thomas Walsh, Development Officer, Centre for Early Childhood Development and Education, St Patrick’s College, Drumcondra, Dublin 9, Ireland Email: Thomas.walsh@spd.dcu.ie
} 
children themselves (Cleary, Nic Ghiolla Phádraig, \& Quin, 2001, p. XV). There is a paucity of research available in the Irish context regarding the general experiences and the lives of children in Ireland in the first part of the twentieth century (Hannan \& Katsiaouni, 1977; Fahey \& McLaughlin, 1999). However, there are a number of contexts in which the lives of children in the past century can be analysed. These include the examination of official policies and reports, anthropological studies and the memoirs of individual writers.

This paper traces the evolution of our concept of childhood as portrayed through the curriculum followed in the primary schools in Ireland in the twentieth century, with a particular focus on the infant classes (ages four to six). Developments are linked to changes in broader political, economic, social and cultural changes in Ireland throughout this time period. The paper is divided into three sections:

1. The curriculum from 1900 to 1922 pre-independence.

2. The curriculum in operation from 1922 to 1971 following independence.

3. The implementation of the child-centred curriculum, 1971-1999.

\section{The Revised Programme 1900-1922}

\section{Political, Economic, Social and Demographic Context}

There have been dramatic and quantum advancements in Irish society in social, economic, demographic, political and cultural terms over the past century. In political terms, at the start of the twentieth century, Ireland was governed by England, with all national affairs decided at Westminster. There had been considerable agitation in Ireland at the close of the nineteenth century in relation to the agrarian situation, political independence, educational reform and cultural revival.

The population was in continuous decline since the Great Famine of 1845-1847 and subsequent famines in the 1870 s and 1880s, while emigration was endemic. The population had decreased from a peak in excess of eight million people in the 1840s to a population of 2.97 million by $1926^{1}$ (Nic Ghiolla Phádraig, 1990, p. 9). The economy at this time, and indeed throughout much of the twentieth century, was largely agrarian-based and highly dependent on Britain for its markets.

\section{Early Childhood Education 1900-1922}

By the end of the nineteenth century, the need for curricular reform within the education system was evident. At this point, the churches had achieved strong proprietorial and managerial rights within the education system, while the Commissioners of National Education for Ireland retained control over the curriculum by the issuing and sanctioning of textbooks. The Commission on Manual and Practical Instruction, commonly known as the Belmore Commission, was established to determine the future role of manual and practical instruction in primary education. Its report in 1898 provided the framework for the 1900 Revised Programme. The 
Commission was greatly influenced by the New Education Movement (see Selleck, 1968) and representatives travelled to Great Britain, mainland Europe and the US to gather evidence for the development of the Revised Programme.

The Revised Programme (1900) advocated the abolition of the Payment by Results system that had been in operation since 1872. In addition, the introduction of a wider curriculum, a focus on kindergarten education, the inclusion of more practical content and an emphasis on schools as an interesting and humane place for children was prioritised. Education was to be enjoyable and discovery-oriented and the inculcation of a disposition for learning was prioritised over actual content. The didactic methodology heretofore used was replaced with a heuristic approach, with an emphasis on practical education (Commission on Manual and Practical Instruction, 1898).

The Belmore Commission Report emphasised the importance of early childhood education and advocated a version of Froebelian education, consisting of kindergarten and traditional subjects. At the heart of Froebel's philosophy was an emphasis on development from within, rather than moulding from the outside. This involved simple manual exercises, the introduction of Froebel's first, second, third and fourth gifts, ${ }^{2}$ singing, drawing, school discipline, physical drill, cookery, laundry and needlework. It is interesting to note the gender segregation in certain subjects, such as needlework, cookery and laundry for girls and woodwork for boys. An emphasis was placed on expression in oral and written terms. Another shift in emphasis was that these subjects were to be taught in an integrated manner when possible, breaking with the tradition of compartmentalising knowledge, which was seen as unnatural for the young child. A great prominence was placed on the child's environment. The result was a radical shift from the old system, widening out the curriculum and introducing a child-centred and practical focus on education.

In educational terms, the Revised Programme of 1900 was the first major policy to affect the quality of early childhood care and education in Ireland. At this point, although attendance was not compulsory in many parts of the country, especially rural areas, many three to six year olds attended primary schools. The curriculum up to 1900 , as previously described, was extremely narrow and academic in character, focusing on examinable subjects. Infants were not a high priority within this system as the success of the older pupils yielded the most profit for the teacher under the system of Payment by Results. However, from 1900:

Infant training was placed at the core of the curriculum, and school life promised to be an enlightening period where children learned largely through play. (O'Connor, 1987a, p. 16)

\section{Implementation of the Revised Programme 1900}

This radical change in emphasis in both the content and methods of instruction led to problems regarding its implementation. This was accentuated by schools that were poorly equipped and where teachers felt little ownership of the reforms. Moreover, 
only $50 \%$ of the existing teachers were trained in traditional methods, operating in unsuitable classrooms and with very low pupil attendance, standing at $63 \%$ in 1901 (Commissioners of National Education, 1901, p. 13). The diminution in funding from the Treasury, owing to the Boer War and other reasons, also impacted negatively on the highly aspirational Revised Programme. Necessary finances for the equipment, training and investment needed for its complete implementation were not provided. The recommendations of the Belmore Commission were never implemented in their entirety and, while the Dale Report of 1904 (Dale, 1904) observed many important improvements in infant classes in the first four years of its implementation, it still cited infant education as one of the weakest elements of the education system. It was particularly concerned with males being in charge of infant classes, as a male was considered unsuitable in disposition for infant teaching:

If there is any point of agreement among all interested in education it is that a man both by temperament and training is unfitted to teach infants, and that the charge of them should be entrusted to a woman. (Dale, 1904, p. 37)

From 1904, a number of small modifications were made to the Revised Programme, but the essence of the curriculum introduced in 1900 remained the dominant curriculum until the advent of the Irish Free State in 1922. The Notes for Teachers issued in 1904 endorsed the kindergarten approach in all infant classes, proposed frequent changes in lessons, the allocation of 10 minutes in every hour for rest and play, and the use of the environment to elicit curiosity. Improvements also occurred in staffing and schools with an enrolment of in excess of 50 pupils were granted a Junior Assistant Mistress in 1904, who would concentrate on kindergarten and the younger classes and provide needlework for the older girls. From 1913, a greater emphasis was placed on the child's environment, recommending the recreation of a home-like environment, while formal teaching for children under five was not to be conducted (O'Connor, 1987a). These guidelines from the Commissioners of National Education show an enhanced understanding of the importance of the environment in learning at this time.

Many subjects were implemented successfully, including drawing, physical education, music and needlework. In addition, the content of readers was transformed and they became more interesting, illustrated and child-centred in focus. Other subjects, including elementary science, cookery and laundry, which required equipment and resources were taught successfully, but in a small number of schools. The introduction of kindergarten and many of the other subjects required the training of teachers in both content and methodology and a number of experts from England were introduced to Ireland for that task over a five-year period.

\section{Conclusion}

There is little evidence of a major change in the concept of childhood in the period 1900-1922 in wider society. However, the period represented somewhat of a 
revolution in the instruction of infants in the formal education sector. The life of pupils in schools was certainly enhanced in this period, availing of a wide and varied curriculum. Additionally, there was a focus on local interests and subjects were taught in a heuristic and discovery-like method. In addition, there was a focus on the social health context of children and there were advancements in relation to healthcare and dental care for pupils. A very different concept of the child as an individual and as a learner was conceived with the Revised Programme of 1900, placing the focus on the child's interests and abilities.

The importance of infant education had been established, the training colleges had taken steps to train teachers in kindergarten and staffing levels had improved. The comprehensive work of the Commission on Manual and Practical Instruction in devising the curriculum is laudable and many of their recommendations would be considered progressive now, a century later. The radical nature of the proposed changes was one of the reasons for their failure to be fully implemented, and O'Connor (1987a, p. 16) notes that this progressive approach to teaching and learning in the infant classes failed to attain recognition in wider society.

\section{Primary School Programme 1922-1971}

\section{Political, Economic, Social and Demographic Context}

In the decades following independence, the Irish government adopted an isolationist policy, and developed an insular attitude regarding international developments (Titley, 1983). The economy at this time was largely agrarian based, and Kennedy (1989, p. XIII) reveals that $40 \%$ of the population in the 1950 s were still employed in agriculture. The percentage of married women in the workforce remained consistently low in this time period, reducing from $5.6 \%$ cent in 1936 to $5.2 \%$ in 1961. All aspects of life, including the family and education, were viewed through a nationalistic and Catholic lens in the period following independence.

The State and Catholic Church ${ }^{3}$ collaborated in the provision of education in the Irish Free State. While the State retained control over the curriculum in operation and its cultural/national focus, the Church maintained control at local level through the ownership and management of schools. The Church vehemently opposed any State interference in family life, and the 1937 Constitution formalised this arrangement (Government of Ireland, 1937). Thus, Church and State assumed a symbiotic relationship, neither interfering with the respective territory each had carved out over the years.

Curriculum was the one area of education for which the State took responsibility. In this period, education was not only perceived to be an end in itself for economic reasons, but:

... rather, the major function of primary education, and for those who went on to secondary education, was religious, moral and intellectual instruction. (Tussing, 1978, p. 54) 
The type of education provided was greatly influenced by the Church, providing an education rich in literacy and morality. As education was not perceived as being a preparation for future employment, there was equal participation of boys and girls. This was unusual in international terms, and an emphasis was placed on literary (English, literature, religion, Irish, Latin, etc.) rather than technical skills (Tussing, 1978, p. 11).

While the decades from independence to the 1960s are prominent for the general lethargy in relation to education and social policy, the economic prosperity of the 1960s facilitated renewed debate and vigour in Irish society (Coolahan, 1981; O'Buachalla, 1989). This is also true in relation to educational matters and the position of children in society, with a new focus on equality of educational opportunity. There was also increased urbanisation, reduced family sizes, a move towards an industrial as opposed to an agrarian economy and increased female participation in the labour force. This led to a renewed concept of the role of education in society.

\section{Curricular Reform 1922-1926}

The involvement of the Gaelic League in the national struggle meant that most of the new government had sympathy, if not an inherent loyalty, to the revival of the Irish language and culture through the education system. This was accentuated by the death of their strongest educational exponent, Patrick Pearse, who had written prolifically on his ideals for the education system in a free Ireland. Curricular reform was perceived as an urgent necessity in an independent Ireland. At the Irish National Teachers' Organisation (INTO) Annual Conference 1920, a resolution was passed for the establishment of the First National Programme Conference. While all relevant stakeholders were invited to participate in order to restructure the curriculum in accordance with Irish ideals and conditions, the Conference was not entirely representative of all interested parties. Revd Timothy Corcoran, a Jesuit Professor of Education at University College Dublin, was one of the most influential educationalists of this era and he acted as an outside advisor to the Conference. He believed a linguistic revival was possible if Irish was introduced in the infant classes:

The early age is the language age. It is not for nothing that small children have fluent, perfected, effortless command of the vocal organs and of the sense of hearing by five years of age. (Corcoran, 1925, p. 380)

He also espoused the doctrine of original sin prevalent in this period, whereby human nature was weakened and inclined towards evil. He further believed that strict authoritarian teaching was required to counteract this inherent failing in children. The existing curriculum was perceived as being overloaded with subjects, neglectful of Irish and out of harmony with national ideals and requirements. Thus, the First National Programme Conference recommended that the Irish language be raised to a 
pre-eminent position, a pruning of the curriculum to allow increased attention on Irish and a distinctive Irish flavour be given to certain subjects (National Programme Conference, 1922).

The curriculum introduced in 1922 was thus tailored to this role, and the breadth and latitude introduced with the Revised Programme of 1900 was once again reduced to a narrow and rigid base. A child-centred curriculum was of little importance in comparison with the restoration of the Irish language, for which the schools were the prime agent of reform (O'Connor, 1987b, p. 5).

The Irish government, in promoting the Irish language, was endeavouring to provide the cultural inheritance it perceived had been denied to previous generations. This was seen as a high priority and duty of the government in the Irish Free State. This programme took a radically different ideological basis from the 1900 Revised Programme and was based on the principle of the revival of cultural nationalism and the Irish language. The Irish language was perceived as the panacea for all problems and, as it was for the good of the nation, it was necessary for the child. In this context, schools were perceived as the means to a politico-nationalistic end (Akenson, 1975, p. 27).

Special emphasis was placed on the infant classes where all instruction was to be in the medium of Irish to ensure a solid basis in the language for the remainder of schooling. English, even as a school subject, was not to be taught in the infant classes. Where the teacher was not competent to instruct through the medium of Irish, there was to be a minimum of one-hour instruction in Irish per day. This affected 250,000 infant class pupils, 90\% of whom spoke English in their homes (O’Cuív, 1966).

A Second National Programme Conference was organised in 1925, to temporarily revise the provisions of the 1922 Conference, taking account of the difficulties in implementing its requirements. This Conference, which was attended by a wider representation of stakeholders, largely endorsed the recommendations of the first Conference. It agreed with instruction of infants through Irish, in so far as was possible, depending on the competency of the teacher. This was relaxed in so far as the instruction in Irish was now compulsory from 10.30 a.m. to 2 p.m. every day. Akenson (1975, p. 47) highlights the success of this programme in the early years; by 1928, 1,240 infant schools were conducted through Irish, 3,570 in both English and Irish, and 373 solely in English. As O'Connor (1987b, p. 5) asserts, the focus on infants for the linguistic revival raised their profile within the system:

By the 1920s infant education had acquired a new status. Infants were no longer to be looked upon as the passive 'babies' of the early nineteenth century. They came to the fore as the leaders of the language revival movement in Ireland. In the New State the success or the failure of Gaelic language in the schools depended largely on the work of the infant classes.

Compulsory attendance was introduced for all pupils aged six to 14 in 1926, promoted on the basis that a child needed to be in school to learn Irish. This met with little opposition, although it had previously been resisted by the Church as an infringement on parents' rights. The 1926 Act was effective in promoting attendance, 
which increased from $69.7 \%$ in 1920 to $83.4 \%$ in 1930 (Commissioners of National Education, 1921; Department of Education, 1931). Corporal punishment was a common feature of school life, and this is evidenced in many accounts of school life in this period (see for example Kavanagh, 1939; Joyce, 1960; Clarke, 1990; Dunne \& Kelly, 2003).

\section{Developments in the 1930s}

The relaxation of rules in the 1926 programme, allowing the teaching of and through English before 10.30 a.m. to facilitate an easier transition for infants, was reversed in 1934. It had become clear that the policy in relation to the Irish language was not succeeding. At this point, the curriculum was further narrowed to afford even greater prominence to the linguistic revival. An emphasis on linguistic attainment in the infant classes remained constant, whereby the teacher was:

... to teach the language as a subject and is to use Irish as much as possible as the medium of instruction and as the school language. (Department of Education, 1934, p. 5)

There were numerous calls for a reform of the primary curriculum, most notably from the INTO, in the proceeding decades but they fell on deaf ears in government circles. The government saw the primary purpose of the education system as cultural nationalism and, despite the fact that this was not being achieved to the desired level, could conceive of no other means to improve it. As the following quote elucidates, Eamonn de Valera, the Taoiseach at the time, focused far more on the product of education than on the process:

I am less interested in the teacher's method of teaching than I am in the results he achieves, and the test I would apply would be the test of an examination. (Dáil Éireann Proceedings, 1943)

While the INTO was committed in ideological terms to the revival, it had serious concerns about the effects of the Irish language programme on the educational development of pupils, as well as on the progress of the language in revival terms. In 1941 it issued a Report of Committee of Inquiry into the use of Irish as a Teaching Medium to Children whose Home Language is English (INTO, 1941). This stated that the majority of infant teachers believed teaching through Irish inhibited the child intellectually, repressed his/her natural urge of expression and led to some children being mentally and physically damaged. However, the Report was not accepted or acted upon by the Minister or the Department at this time (O'Connell, 1968). O'Connor (1987b, p. 6) believes that the emphasis on the Irish language in this time period had a detrimental effect on infant education as a whole:

... one tends to incline to the notion, in the light of available evidence, that the attempt to further the Gaelic ideal militated against enlightened infant pedagogy. 


\section{Curricular Reform 1948}

In 1948, a revised programme for infants was introduced under the then Minister for Education, Richard Mulcahy. This allowed for the reintroduction of the half an hour of English teaching in infant classrooms per day, which had been abolished in 1934. This was optional, based on the teacher's discretion. In this Revised Programme for Infants of 1948, we see a return to the principles and ideology of the 1900 Programme, advocating:

The aim of the Infant School is to provide the atmosphere and background in which the child's whole personality may develop naturally and easily. It should therefore take cognisance of the child's interests, activities and speech needs, and utilize them to the full in aiding and directing such developments. (Department of Education, 1948, p. 5)

The 1948 programme aspired to give children a vernacular command of Irish with the intention that Irish would become the sole language of the infant school as early as possible. The infant teachers adopted the new programme with mixed feelings, focusing on its positive features but also aware that it presupposed an abundance of resources that simply did not exist. "Notes for Teachers" followed in 1951 (Department of Education, 1951). These outlined the content and method for the infant classes and allowed the programme to be adapted for smaller schools with mixed classes. This encouraged children to play a more active role in their own education, the recognition and facilitation of individual differences, individual and group learning, and a heuristic approach to education as advocated in 1900:

The purpose of the infant school is to provide for young children the environment, opportunities and activities most favourable to their full development. Infant teaching if it is to be successful, must be based on the young child's instinctive urge to play, to talk, to imitate, to manipulate materials, to make and do things. (Department of Education, 1951, p. 3)

O'Connor (1987b, p. 6) asserts that “... a new era had dawned...” for infant education in 1948. The progressive nature of the infant curriculum inspired the use of such principles and methodologies in senior classes. Despite a lapse of in excess of 20 years, this revision influenced the development of the 1971 Primary School Curriculum.

In 1960, the Department of Education issued Circular 11/60, giving the infant teacher the choice between using Irish as a medium of instruction and having Irish as a subject only (Department of Education, 1960).

\section{Council of Education 1950-1954}

The Council of Education was set up in 1950 to review the primary school curriculum. It was issued with narrow terms of reference and largely excluded parents 
and the wider educational community from the consultative process. The Council of Education Report in 1954 concluded that there was little need for reform and, despite some internal debate within the membership, the Report expressed a general satisfaction with the status quo. Consequently, it did not have a substantial impact on policy developments in this period.

The Council disagreed with many of the submissions it received calling for a wider curriculum, preferring a higher standard in core subjects (Department of Education, 1954, p. 118). The Infant curriculum introduced in 1948 was adopted by the Council and, despite concerns about its nature and content, it made no steps to alter its structure. There was much criticism regarding the introduction of Irish in the infant classes but the Council endorsed the prevailing status quo, citing the benefits of giving children an ability in both English (30 minutes per day) and Irish (remainder of the day) at this early age.

\section{Developments in the 1960s}

Groups in Ireland such as Tuairim, established in 1954 to encourage people to express their "opinion" on issues they thought neglected in Irish society, expressed concerns about the education system. In particular, the rigid curriculum, the emphasis on examinations, the neglect of the slow learner, the lack of research in education and the Report of the Council of Education were criticised (Tuairim, 1962). From the mid-1960s onwards, there was little mention of the spiritual or nationalist side of education, the focus having shifted to the role of the education system as an investment in economic growth and national prosperity.

The economic upturn of the 1960s also allowed more investment in resources and facilities for schools. The report Investment in Education (Department of Education, 1965), the background paper for the Organisation for Economic Cooperation and Development review team, proved a catalyst in the drive for reform and was used as leverage to yield increased funding for education. It exposed many inadequacies within the education system, the final report asserting that:

... Ireland is faced with the necessity to carry out a thorough reform of its educational system. (Organisation for Economic Cooperation and Development, 1969, p. 47)

A background dossier for a planned White Paper on Education elucidates many of the problems with the curriculum at this point, in that it:

... tends to treat children as if they were identical, environment as if it were irrelevant, and subject content as if it were easily defined. Its greatest fault, perhaps, is that it fails to look on education as a trail of discovery, enrichment and understanding for the growing child, and sees it instead as a logical structure 
containing conveniently differentiated parts which may be imposed by adults on children. (Department of Education, 1967, p. 40)

The primary inspectorate had already begun to draft a new curriculum in line with modern thinking on the nature of the child and his/her learning needs for the primary school.

Moreover, Ireland's Third Programme for Economic Expansion (Government of Ireland, 1969) announced the widening of the curriculum, reduced pupil-teacher ratios and the provision of remedial teachers for children with learning difficulties. Prior to this, whatever additional supports were available were for children with specific disabilities rather than general learning difficulties. Limited services had previously been provided largely by the religious orders, and Coolahan (1989, p. 46) notes the significance of State intervention in this regard, reflecting "... the greater concern for the welfare of the individual pupil that has become evident in recent decades."

\section{Conclusion}

The emphasis in the curriculum in this period was on a linguistic and cultural revival, and on moralistic and literary content. This led to a narrowing of the wide curriculum that had been in use from 1900 to 1922 . To accommodate this, children in schools came to the fore in the cultural revival and it can be argued that their education in this period may have suffered, as it was not premised on the needs of the child. Infant classes were specially targeted for language transmission and the practice of instruction through Irish in these classes was introduced. The curriculum became increasingly narrow when it became apparent that the use of the Irish language was not becoming as widespread as was hoped. The focus on the Irish language and the transmission of the cultural heritage remained a feature of the primary curriculum until the 1960s, thus retaining a narrow and rigid curriculum. Prior to the 1960s, the purpose of the education system could be summarised as to teach children to save their souls and "... to love all things Irish". (Donagh, 1993, p. 336) There was little expansion in the system in the period 1920-1960, a clear philosophy of education had not been laid out and the entire system was governed by deep caution on the part of Church and State.

The concept of childhood in this period, as espoused by the Primary school programme, is as a vehicle for the promotion of political, cultural and nationalist objectives. The curriculum gave little regard to the needs, interests or abilities of the individual child. At the same time, there was a strong emphasis on didactic teaching and punishment, emanating from the belief in the doctrine of original sin. There is much evidence from this period that school life was often difficult and joyless for the child, and did not prepare children adequately for the lives they were to lead subsequently in Ireland or abroad. 


\title{
Primary School Curriculum 1971-1999
}

\section{Political, Economic, Social and Demographic Context}

Developments in the 1960s led to the realisation of the need for a radical reform of the Primary School Curriculum in congruence with the developing understandings of children and child development. It was also seen as necessary to align the education system with the needs of an expanding economy. There was a growing public interest in the education system, and parents saw education as the vehicle for social mobility for their children. In addition, Ireland's insularity since Independence was beginning to abate and increased contacts with international groups such as the Organisation for Economic Cooperation and Development, the United Nations Educational, Scientific and Cultural Organisation and the United Nations catalysed a change in thinking of education as a social expenditure to one of investment in people, the economy and society. However, the prosperity and optimism of the 1960s were followed by economic recession in the 1970s and 1980s, and many of the proposed schemes and resources for education were affected by budgetary contractions on social spending.

Emigration remained high until the 1990s, when the embryonic stages of the "Tiger Economy" began to emerge. The improved economic status of Ireland facilitated educational expansion and development, and a multiplicity of initiatives and reforms were introduced. By the end of the 1990s, all aspects and levels of Irish education had undergone fundamental reform and reappraisal. Economic expansion necessitated the entry of increased numbers into the workforce, including many women (and mothers), which in turn led to changes in the way children are cared for and educated in society. The population continued to increase throughout the 1990s, owing to reduced emigration and increased immigration to Ireland.

\section{Early Years Education}

The 1971 Curriculum described the preceding curriculum aptly, highlighting the narrow focus of the curriculum and the focus on knowledge-transfer as opposed to learning dispositions and discovery learning:

\begin{abstract}
This may have led to a certain uniformity of standards: it certainly resulted in a general uniformity of practice. Education was 'curriculum-centred' rather than 'child-centred', and the teacher's function in many cases, was that of a medium through whom knowledge was merely transferred to his pupils. (Department of Education, 1971, p. 15)
\end{abstract}

Like its predecessors of 1900 and 1922, the 1971 curriculum was a radical shift from the existing system in operation and returned to the child-centred, heuristic and discovery-learning ideals of the 1900 Revised Programme. The 1971 curriculum had two main aims: 
1. To enable the child to live a full life as a child and;

2. To equip him to avail himself of further education so that he may go on to live a full and useful life as an adult in society. (Department of Education, 1971, p. 12)

These aims were based on two implicit factors:

1. All children are complex human beings with physical, emotional, intellectual and spiritual needs and potentialities and;

2. Because each child is an individual, he [sic] deserves to be valued for himself and to be provided with the kind and variety of opportunities towards stimulation and fulfilment that will enable him to develop his natural powers at his own rate to his fullest capacity. (Department of Education, 1971, p. 12)

Thus, the curriculum was designed to cater for the full and harmonious development of each individual child, with the inherent flexibility to adapt to the needs of children of varying abilities, natural endowment and cultural background. Great use was to be made of the local environment and concrete objects in the child's learning environment. An emphasis was also placed on individual and small-group learning as opposed to whole class teaching. The role of the teacher was also transformed:

The teacher is no longer regarded as one who merely imparts information but rather as one who provides suitable learning situations and who guides and stimulates the child in his pursuit of knowledge. (Department of Education, 1971, p. 18)

This allowed children to play a more active role in their education, leading to greater self-reliance, confidence and flexibility. Continuity in content and methodology was viewed as being of paramount importance. It was recognised that content was of course important, but so too was the disposition towards learning created through the manner of teaching, attitudes and enthusiasm of teachers. The child was now perceived as an active agent in his/her own education, working individually to promote independence and self-reliance and working in groups to promote cooperation and social development. Implicit in the 1971 curriculum was the recognition of childhood as a distinct period of human development. The curriculum was viewed as an integral whole and all subjects were to be taught in an integrated way rather than the previous method of compartmentalisation. It was a radical shift from the practice of the previous half-century, placing the child at the centre of the learning experience and adopting modern methodologies (Coolahan, 1981, p. 170).

A comprehensive network of supports for teachers was envisaged to assist principals and teachers to adapt and utilise the New Curriculum. However, the recession in the 1970s caused major cutbacks in spending on education. Moreover, many parents were confused by the new principles and ideologies underpinning the curriculum and there was inadequate communication with post-primary schools to ensure continuity in education upon transition (Hyland, 1987). While the New 
Curriculum was introduced, it did not happen as quickly or as comprehensively as was hoped:

Problems emerged in the implementation of the New Curriculum (1971) such as the high pupil-teacher ratios and poorly designed classrooms for the new methodologies, while the lack of in-service education impacted upon understanding, ownership and willingness of the teachers to implement the changes. (O’Sullivan, 1980, p. 392)

This is evident in the White Paper on Educational Development (Department of Education, 1980, p. 25) when it expresses certain reservations that the outcomes of the new curriculum were intangible in comparison with the more rigid earlier curriculum.

The emphasis placed on the child-centred philosophy raised awareness of the inappropriateness of corporal punishment, which was used widely in schools at this time (Coolahan, 1981, p. 180). The abolition of corporal punishment in 1982 by Ministerial directive further reinforced the child-centred nature of the curriculum.

\section{Developments in the 1980s and 1990s}

The publication of government policy in the form of a White Paper on Educational Development in 1980 (Department of Education, 1980) and a Programme for Action in Education (Department of Education, 1984) has been followed through and enhanced in the 1990s, allowing greater transparency in policy development in the quest to meet goals and objectives. The Primary School Curriculum (1971) was implemented until 1999. A process of curricular reform was instigated in 1990 with the publication of the Report of the Primary Education Review Body (Department of Education, 1990) and, following a lengthy consultation and partnership process, the Primary School Curriculum (Department of Education and Science, 1999) was introduced. This builds on the philosophies and principles of the 1971 Curriculum and endeavours to prepare children for life in the twenty-first century.

\section{Conclusion}

Within the education system, this era heralded the introduction of a child-centred curriculum in 1971, placing a special emphasis on early childhood education. Methodologies were improved and greater use was made of the environment and previous experiences of the child. Economic prosperity catalysed many reforms in the early years of this period, but subsequent recessions marred the implementation of the aspirational proposals for the education system. The pupil-teacher ratio declined quite substantially during this period and spending on education increased. Advancements include a special focus on children affected by disadvantage and those with special needs. 


\section{Overview and Conclusion}

Ireland's policies in relation to children have been influenced by both national and international developments throughout the century. The nature of education varied in this period, as the curriculum was adapted for particular national, cultural and economic needs, as well as evolving in line with pedagogical and educational advancements. As Horgan and Douglas (2001, p. 139) state:

In the State sector, in this country, the curricular pendulum since 1831 has oscillated back and forth from the traditional, didactic approach to childcentredness.

This paper has traced this oscillation through its various phases, the latter being a child-centred and heuristic curriculum underpinned by an apposite discovery learning methodology. This was a welcome and long overdue transition from earlier curricular focuses and methodologies that did not always place the child at the core. Even though this was not formally implemented until 1971, there had been a growing awareness and move towards child-centred education from the late 1950s. The current Primary School Curriculum (Department of Education and Science, 1999) reinforces the underlying principles of the 1971 curriculum and provides ongoing professional development in the implementation of the curriculum. It is hoped that educational provision will continue along this vein, placing the needs, ability and interests of the child at the core of the educational process.

\section{Notes}

[1] Note that the population in the 1840 s relates to the 32 counties of Ireland, while the figure for 1926 applies to the 26 counties of the Irish Free State.

[2] Gifts in Froebelian philosophy are "designed apparatus" or "geometric shapes" designed to give the child an insight into the structure and meaning of the world, such as soft balls, wooden spheres, cubes, oblongs and prisms. Occupations were activities that were developed to give expression to these ideas.

[3] The Catholic Church was the Church of the majority of citizens throughout the twentieth century. Reference to the "Church" in this article refers to the Catholic Church, unless otherwise stated.

\section{References}

Akenson, D. (1975). A mirror to Kathleen's face-Education in independent Ireland 1922-1960. London: McGill-Queen's University Press.

Clarke, A. (1990). Twice round the black church-Early memories of Ireland and England. Dublin: Moytura Press.

Cleary, A., Nic Ghiolla Phádraig, M., \& Quin, S. (Eds.). (2001). Understanding children, Volume 2Changing experiences and family forms. Dublin: Oak Tree Press.

Commission on Manual and Practical Instruction. (1898). Final report of the commission on manual and practical instruction in primary schools under the board of national education in Ireland. Dublin: Printed for her Majesty's Stationery Office by Alexander Thom and Co. 
Commissioners of National Education. (1901). 68th report of the commissioners of national education in Ireland for 1901. Dublin: Alexander Thom and Co.

Commissioners of National Education. (1921). 86th report of the commissioners of national education in Ireland for 1919-1920. Dublin: Alexander Thom and Co.

Coolahan, J. (1981). Irish education-History and structure. Dublin: Institute of Public Administration.

Coolahan (1989). Educational policy for national schools 1960-1985. In D. Mulcahy, \& D. O'Sullivan (Eds.), Irish educational policy-Process and substance (pp. 27-76). Dublin: Institute of Public Administration.

Corcoran, T. (1925). The Irish language in the schools. Studies, XIV, 337-388.

Dáil Éireann Proceedings. (1943). Volume 83, Column 1097, 27 May 1941.

Dale, F. (1904). Report of Mr. F.H. Dale, His Majesty's Inspector of Schools, board of education, on primary education in Ireland. Dublin: Alexander Thom and Co.

Department of Education. (1931). Report of the Department of Education 1929-30. Dublin: The Stationery Office.

Department of Education. (1934). Revised programme of primary instruction. Dublin: The Wood Printing Works.

Department of Education. (1948). Revised programme for infants. Dublin: The Stationery Office.

Department of Education. (1951). An Nai-Scoil. Dublin: The Stationery Office.

Department of Education. (1954). Report of the Council of Education. Dublin: The Stationery Office.

Department of Education. (1960). Circular 11/60-Múineadh na Gaeilge. Dublin: The Stationery Office.

Department of Education. (1965). Investment in education. Dublin: The Stationery Office.

Department of Education.. (1967). Background paper of the steering committee on the planned white paper on education. (Unpublished paper, Department of Education, Dublin).

Department of Education. (1971). Primary school curriculum: Teacher's handbooks. Dublin: The Stationery Office.

Department of Education. (1980). White paper on educational development. Dublin: The Stationery Office.

Department of Education. (1984). Programme for action in education 1984-1987. Dublin: The Stationery Office.

Department of Education. (1990). Report of the primary education review body. Dublin: The Stationery Office.

Department of Education and Science. (1999). Primary school curriculum. Dublin: The Stationery Office.

Donagh, M. (1993). The emergence of an economic dimension in Irish education policy and planning during the 1960s. MEd Thesis, University College Cork.

Dunne, J., \& Kelly, J. (2003). Changing perspectives on childhoods. In J. Dunne, \& J. Kelly (Eds.), Childhood and its discontents - The first Seamus Heaney lectures (pp. 1-30). Dublin: The Liffey Press.

Fahey, T., \& McLaughlin, E. (1999). Family and the state. In A. Heath, R. Breen, \& C. Whelan (Eds.), Ireland north and south-Perspectives from social science (pp. 117-140). New York: Oxford University Press.

Government of Ireland. (1937). Bunreacht na hEireann-Constitution of Ireland. Dublin: The Stationery Office.

Government of Ireland. (1969). Irelands third programme for economic expansion. Dublin: The Stationery Office.

Hannan, D., \& Katsiaouni, L. (1977). Traditional families? From culturally prescribed to negotiated roles in farm families. Dublin: The Economic and Social Research Institute.

Horgan, M., \& Douglas, F. (2001). Some aspects of quality in early childhood education. In A. Cleary, M. Nic Ghiolla Phádraig, \& S. Quin (Eds.), Understanding children, Volume 1-State, education and economy (pp. 119-144). Dublin: Oak Tree Press. 
Hyland, A. (1987). The process of curriculum change in the Irish national school system. Irish Educational Studies, 6(2), 17-38.

Irish National Teachers' Organisation. (1941). Report of the committee of inquiry into the use of Irish as a teaching medium of children whose home language is English. Dublin: Irish National Teachers' Organisation.

Joyce, J. (1960). A portrait of the artist as a young man. New York: Penguin Books.

Kavanagh, P. (1939). The green fool. New York: Harper and Brothers.

Kennedy, F. (1989). Family, economy and government in Ireland. Dublin: The Economic and Social Research Institute.

NationalProgramme Conference. (1922). National programme of primary instruction. Dublin: The Educational Company of Ireland.

Nic Ghiolla Phádraig, M. (1990). Childhood as a social phenomenon-National report Ireland (Eurosocial Report 36/8). Vienna: European Centre for Social Welfare Policy and Research.

O'Buachalla, S. (1989). Education policy in twentieth century Ireland. Dublin: Wolfhound Press.

O'Connell, T. (1968). 100 years of progress - The story of the Irish national teachers' organisation 1868-1968. Dublin: Dakota Press.

O'Connor, M. (1987a). The development of infant education in Ireland 1900-1971. An Múinteoir, 1(3), 15-17.

O’Connor, M. (1987b). Infant education in independent Ireland 1922-1971. An Múinteoir, 2(1), 5-7.

Ó Cuív, B. (1966). Education and language. In D. Williams (Ed.), The Irish struggle 1916-1926 (p. 162). London: Routledge and Kegan Paul.

Organisation for Economic Cooperation and Development. (1969). Reviews of national policies for education-Ireland. Paris: OECD.

O'Sullivan, D. (1980). Teacher socialisation and teaching style in an Irish cultural context. European Journal of Education, 15(4), 387-397.

Selleck, R. (1968). The new education - The English background 1870-1914. Melbourne: Sir Isaac Pitman and Sons.

Smyth, M. (2003). The concept of childhood and the experience of children in violently divided societies. In J. Dunne, \& J. Kelly (Eds.), Childhood and its discontents - The first Seamus Heaney lectures (pp. 159-198). Dublin: The Liffey Press.

Titley, B. (1983). Church, state and the control of schooling in Ireland 1900-1944. Dublin: Gill and Macmillan.

Tuairim (1962). Irish education. London: Tuairim.

Tussing, A. (1978). Irish educational expenditures - Past, present and future. Dublin: The Economic and Social Research Institute. 